\title{
TANGIBLE ASSETS DEPRECIATION ISSUES
}

\begin{abstract}
Buildings, machinery, equipment, furniture, computers, parking lots, cars, and trucks are examples of tangible assets that will not last indefinitely, but more than one year. During each accounting period, a portion of the cost of these assets is being used up. Each company, due its establishment, procures tangible assets as the base for its operation. If you are responsible person (CEO) in the production company, it is not unusual if you find out that some of your production assets are still in operation, but they were completely depreciated. By this way, main accounting principles for reporting on tangible assets (cost and revenue matching principle) are not respected. The way the CEO solve this problem can have big impact on costing price and profit or loss at the end of the year. Problem is that useful life of asset was not properly assessed or revised. As result, carrying amount and income in financial statements are not correct. Solving these problems is very important for creating consolidation statements and representing financial statements due to International Financial Reporting Standards, especially if large audit firms audit financial statements. The aim of this work is to help understanding theoretical and practical issues on tangible assets, especially depreciation, trough analyzing available literature, scientific works written world abroad and practical research made by author.
\end{abstract}

Key words: tangible assets, depreciation, useful life, revaluation.

JEL: $M 41$

\section{INTRODUCTION}

Through preparing tangible assets information needed for mergers and acquisition, as well as assisting the authorized assessor assessing the economic value of tangible assets, I faced with one very common issue. Companies have many tangible assets that are still in use, but have been fully depreciated. As a result, huge profits or losses are recorded on sale of these assets or the company's assets are depreciated while their fair value goes up. A tremendous amount of companies makes this mistake.

1 MA, Faculty of Economics - University of Zenica, Zenica, 72000, Boosnia and Herzegovina, E-mail: inella.karic@hotmail.com 
My experience in accounting and auditing tasks showed that this is something that is regularly being forgotten. It has big importance especially in cases of mergers and acquisitions, since there are assets that are in off-balance sheet.

During a transitional period of big after-war privatization in Bosnia and Herzegovina, many ex-giant companies were sold for few notes. The State representatives obviously did not calculate on the off-balance sheet assets, when calculating the value of a company. As a result, many tangible assets were given for free. If an asset does not have a depreciable amount, it does not mean that it has no value. Incorrect estimation of depreciation percentage of tangible assets within a useful timeframe is one the biggest IFRS financial statements mistakes. If a company wants to avoid an accounting scandal or even worse penalties, the financial statements should be error-free.

The aim of this professional article is to remember what is already known about depreciation of tangible assets as well to emphasis of the dissemination of knowledge how to avoid and correct mistake in accounting estimation. An article should be an introduction for one broadly research of depreciation impacts on IFRS financial statements. Therefore, the hypothesis is:

Incorrect depreciable amount in IFRS financial statements is not a result of different depreciation methods application, but inconsistent application changes in accounting estimates. It was proved through appliance of analyzing and synchronous result comparison methods, so in the same way it brings a conclusion.

\section{Prior literature and theory}

Company's assets are classified into fixed assets and current assets. Fixed assets are used in the business for earning profit. They are not meant for sale in the ordinary course of business. The benefit of fixed asset spreads for more than one accounting period. Fixed assets would generate revenue until the end of their useful life. When the fixed assets are used to earn revenue, it is necessary that the cost of the fixed assets be charged over the useful life of the assets. It is necessary to charge the appropriate portion of the cost of fixed asset against its revenue to give meaning to the concept of accounting principle - "Matching concept" (Ramagopal, C., 2009, p. 156). Fixed assets can be tangible and intangible.

International accounting standard, IAS 16 - Property, Plant and Equipment has objective to prescribe the accounting treatment for property, plant and equipment (tangible assets). 
IAS 16.6 defines property, plant and equipment are tangible items that:

1. Are held for use in the production or supply of goods or services, for rental to others, or for administrative purposes; and

2. Are expected to be used during more than one period.

It defines depreciation as ,the systematic allocation of the depreciable amount of an asset over its useful life". Depreciable amount is the original value diminished for cost of the asset less its residual scrap value.

Stittle, J. \& Robert T.W. (2008, p. 47) state that depreciation should be allocated to accounting periods so as to charge a fair proportion to each accounting period during the expected useful life of the asset. In the assessment and allocation of depreciation to accounting periods, three key factors that need to be considered:

- Cost (or valuation - if the asset has been revalued);

- Nature of the asset and the length of its expected useful life to the business, having due regard to the incidence of obsolescence;

- Estimated residual (or scrap) value.

The fixed assets of a business will usually be purchased in one accounting period but will normally last for many future years. These fixed assets, consisting of items such as buildings, computers, plant and machinery, etc. will be used in the business to generate future earnings for many years, and in the case of buildings, perhaps for many decades. Legally and also in accordance with accounting standards, the cost of an asset must be allocated over the period expected to benefit from its use. The UK accounting standard FRS 15, Tangible fixed assets, states that the fundamental objective of depreciation is to reflect in the operating profit the cost of using tangible assets. In other words, when a company uses a fixed asset, it is consuming economic resources and these should be reflected in the financial statements during the useful economic life of the asset. (Stittle, J. \& Robert T.W., 2008, p. 46).

Ramagopal, C. (2009, p. 156-157) defines depreciation as the diminution in the value of the fixed assets because of their use, wear and tear, efflux of time, depletion etc. It is permanent, continuing and gradual shrinkage in the book value of a fixed asset. It is an invisible expense and there is no actual cash outgo of funds from the firm. Depreciation charges reduces profits, so if depreciation is not provided, operational results would be overstated.

Gangwar, S. \& Gangwar, D.K., (2008, p. 243) state that depreciation is the accounting practice where the cost of fixed assets is systematically spread over the life of the assets. The amount of depreciation has the effect of reducing the profit or raising the loss for the periods during which the asset is used. As depreciation is a noncash expense, it allows the money to be retained in the business. 
(Stittle, J. \& Robert T.W., 2008) notes that in a conceptual sense, depreciation attempts to ensure that a company does not deplete its capital base. So if a company does not provide for depreciation of its fixed assets in its profit and loss account, the company's earnings will, in relative terms, be overstated. If the earnings are overstated by not providing for depreciation, then, excessively high levels of profit (or dividends) could be taken out of the business. As a result, the accounting danger is that profits and dividends are distributed from the capital base of the business, which in effect depletes the capital of the business. To assist in maintaining the capital base of business, it is important that a provision is made for the depreciation of the fixed assets that were originally acquired. The accounting process of making this provision is by including a depreciation charge in the profit and loss account of the business.

Rauf, S. B. (2010, p. 135) states that depreciation plays an important role in accounting for the attrition in the useful life of assets and it has direct impact on the bottom line, or the net income. Typically, program managers, project managers, production managers and energy engineers are not directly influenced by depreciation, in most cases they make decision that have direct ramifications on depreciation.

National Association of Regulatory Utility Commissioners - NARUC defines depreciation as the loss in service value not restored by current maintenance, incurred in connection with the consumption or prospective retirement of utility plant in the course of service from causes that are known to be in current operation and against which the utility is not protected by insurance. Among the causes to be given consideration are wear and tear, decay, action of the elements, inadequacy, obsolescence, and requirements of public authorities (Bui, T. A., 2011).

\section{Methods of depreciation}

The depreciation method used shall reflect the pattern in which the asset's future economic benefits are expected to be consumed by the entity (IAS 16.60). The depreciation method applied to an asset shall be reviewed at least at each financial year-end and, if there has been a significant change in the expected pattern of consumption of the future economic benefits embodied in the asset, the method shall be changed to reflect the changed pattern. Such a change shall be accounted for as a change in an accounting estimate in accordance with IAS 8 (IAS 16.60).

The method of providing depreciation has to be consistent from year to year. However, firm may change the existing method of depreciation to a new method of depreciation, by observing certain requirements (Ramagopal, 2009, p. 160).

IAS 16.62 notes that a variety of depreciation methods that can be used. These methods include the straight-line method, the diminishing balance method and the units 
of production method. The entity selects the method that most closely reflects the expected pattern of consumption of the future economic benefits embodied in the asset. That method is applied consistently from period to period unless there is a change in the expected pattern of consumption of those future economic benefits. Selection of the depreciation method and estimation of the useful life of assets are matters of judgement. Therefore, disclosure of the methods adopted and the estimated useful lives or depreciation rates provides users of financial statements with information that allows them to review the policies selected by management and enables comparisons to be made with other entities (IAS 16.75).

Companies can develop reasonable estimates for lives to be assigned to newly acquired assets by reviewing actual usage of existing assets. Assets still in use, but fully written off, represent past errors in the estimated life, an error that need not be repeated (King, A. M., 2011, p. 51).

Estimated service life based on retirement experience or other information must be adjusted in light of available information regarding probable future conditions affecting the service life of the depreciable asset. Future conditions may alter the relative effect of causes (physical and functional) of depreciation that existed in the past. In brief, estimates of future service lives of assets are subjective and can reflect only the best-informed judgment (Ann, T. B., 2011).

Due to Stittle, J. \& Robert T.W. (2008) the three most common depreciation methods are:

- Straight-line method;

- Reducing balance method (diminishing balance method);

- Sum of years' digits method.

The difference in depreciation methods involves when you will report the depreciation. It is a matter of timing. Again, the total depreciation during the life of the asset is the same regardless of the depreciation method used.

\subsection{Straight-line method}

Straight-line depreciation results in a constant charge over the useful life if the asset's residual value does not change (IAS 16.62). Under this commonly used method of depreciation, an equal charge for depreciation is entered into the profit and loss account each year (Stittle, J. \& Robert T.W., 2008). In the balance sheet of the business, the fixed asset will be shown at its net amount (i.e. less depreciation). 
For example, Company Eco has purchased a vehicle for $€ 20.000,00$, on third January 2015 an accounting year. It is decided that this machine will have useful life of 5 years. At the end of its useful life, the company expects to sell the equipment for $€$ $3.000,00$ (scrap value). It would be good if in additional booking records, company make register with following details:

Table 1: Fixed asset register for Mercedes-Benz with reference number 01223654

\begin{tabular}{lr}
\hline & FIXED ASSET REGISTER \\
\hline NAME OF ASSET & Mercedes Benz \\
\hline PRIMARY ACCOUNT CLASSIFICATION & Vehicles and equipment \\
\hline DESCRIPTION & 1224 ATEGO \\
\hline REFERENCE NUMBER & F222333675W \\
\hline PURCHASING DATE & 03.01 .2015$. \\
\hline ESTIMATED USEFUL LIFE & 5 \\
\hline LOCATION IN COMPANY & Raw material warehouse \\
\hline ORIGNAL COST (VALUE) & $€ 20.000,00$ \\
\hline MANAGER RESPONSIBILITY & Stock D. \\
\hline SCRAP VALUE & $€ 3000,00$ \\
\hline DEPRECIATION RATE & $17 \%$ \\
\hline REFERENCE NUMBER & 01223654 \\
\hline
\end{tabular}

\section{Source: Author}

Calculations: $^{2}$

Original value

Scrap value

Depreciable cost

$$
\begin{array}{lrl}
= & 20.000,00 & (100 \%) \\
= & 3.000,00 & (15 \% \text { of original cost }) \\
= & 17.000,00 & (85 \% \text { of original cost }) \\
& &
\end{array}
$$

Annual depreciation rate $=\frac{85 \%}{\text { Estimated useful life }}=\frac{85 \%}{5}=17 \%$ of original $\cos (€ 3.400,00$ per year $)$

The depreciation charge for every year, which will be shown in $\mathrm{P} / \mathrm{L}$ account, will be $€ 3.400,00$. Deeper insight in an account for transportation equipment in balance sheet, will give information on purchase value, as well as accumulated depreciation of transportation equipment as follows:

2 The streight-line rate may be expressed and as a percentage of depreciable cost, an annual rate is $20 \%$ of depreciable cost. 
Table 2: Analytical records for fixed asset Mercedes-Benz

\begin{tabular}{|c|c|c|c|c|c|c|c|c|}
\hline \multirow[b]{2}{*}{ Date } & \multirow[b]{2}{*}{ Description } & \multicolumn{3}{|c|}{ Mercedes asset account } & \multicolumn{3}{|c|}{ Accumulated depreciation } & \multirow{2}{*}{$\begin{array}{l}\text { Net book } \\
\text { value }\end{array}$} \\
\hline & & Debit & Credit & Balance & Debit & Credit & Balance & \\
\hline 3 January 2015 & $\begin{array}{l}\text { Purchase } \\
\text { of an Asset }\end{array}$ & $€ 20.000,00$ & & $€ 20.000,00$ & & & & $€ 20.000,00$ \\
\hline $\begin{array}{l}31 \text { December } \\
2015\end{array}$ & $\begin{array}{c}\text { Annual } \\
\text { Depreciation }\end{array}$ & & & & & $€ 3.400,00$ & $€ 3.400,00$ & $€ 16.600,00$ \\
\hline $\begin{array}{l}31 \text { December } \\
2016\end{array}$ & $\begin{array}{c}\text { Annual } \\
\text { Depreciation }\end{array}$ & & & & & $€ 3.400,00$ & $€ 6.800,00$ & $€ 13.200,00$ \\
\hline $\begin{array}{l}\text { 31 December } \\
2017\end{array}$ & $\begin{array}{c}\text { Annual } \\
\text { Depreciation }\end{array}$ & & & & & $€ 3.400,00$ & $€ 10.200,00$ & $€ 9.800,00$ \\
\hline $\begin{array}{l}\text { 31 December } \\
2018\end{array}$ & $\begin{array}{c}\text { Annual } \\
\text { Depreciation }\end{array}$ & & & & & $€ 3.400,00$ & $€ 13.600,00$ & $€ 6.400,00$ \\
\hline $\begin{array}{l}31 \text { December } \\
2019\end{array}$ & $\begin{array}{c}\text { Annual } \\
\text { Depreciation }\end{array}$ & & & & & $€ 3.400,00$ & $€ 17.000,00$ & $€ 3.000,00$ \\
\hline
\end{tabular}

Source: Author

An advantage of the straight-line method is that it is simple to apply. On the other hand, its simplicity means that it is less likely to accord with economic reality or the way in which we normally think assets behave (or lose value) over time. (Stittle, J. \& Robert T.W., 2008, p. 47). The straight-line method assumes that time expiration is the sole factor, other than asset cost and net salvage value, determining the depreciation charge. It is unlikely that the service value of an asset will expire uniformly throughout the service life of that asset; physical and functional factors that limit service life may cause more loss in service value of an asset in one period than in another. However, unless there is sufficient evidence that the rate of service value expiration differs substantially from one period to another (such as where service value expiration is caused by primarily wear and tear from use), the assumption of uniform service life expiration is not unreasonable. In contrast to other depreciation methods, the straight-line method readily permits the recalculation of depreciation charges-based on changing estimates of service lives or net salvage values (Ann T. B, 2011).

\subsection{Reducing balance method}

The diminishing balance method results in a decreasing charge over the useful life. The units of production method results in a charge based on the expected use or output (IAS 16.62). 
Stittle, J. \& Robert T.W. (2008, p. 48) describes reducing balance method as an accelerated method. Under this method, a fixed percentage rate of deprecation charge is applied to the fixed assets. The actual percentage charge can be mathematically calculated, although many companies choose to use a reasonably practical percentage figure for calculation. The particular percentage used will depend on their own experience of the types of assets used by the business. Each year's depreciation charge in the profit and loss account will vary in size and become progressively less as the years pass. The idea that depreciation charges will reduce over time has some intuitive appeal. For instance, a new branded car will lose a substantial amount of initial value in the first year after purchase. An advantage of the reducing balance method seems to accord more with economic reality than does the straight-line method, but on the other side it is more complicated to apply in practice, and it could be calculated by using the following formula:

$$
r=1-\sqrt[n]{\frac{s}{C}}
$$

$\mathrm{r}=$ annual depreciation rate

$\mathrm{n}=$ years of useful life

$\mathrm{s}=$ residual value

$\mathrm{c}=$ recorded cost

By using the same data as in the straight-line method, annual depreciation rate could be calculated as follows:

$$
r=1-\sqrt[5]{\frac{3000}{20000}}=1-0,68425=31,57 \%
$$

The entries in profit and loss account and balance sheet would be as follows:

Table 3: Reducing balance method calculation

\begin{tabular}{ccccccc}
\hline Date & Original value & Calculation & Depreciation & \multicolumn{2}{c}{ Net book value } \\
\hline 31 December 2015 & $€$ & $20.000,00$ & $20000,00 \times 31,57 \%$ & $6.314,00$ & $€$ & $13.686,00$ \\
\hline 31 December 2016 & $€$ & $20.000,00$ & $13686,00 \times 31,57 \%$ & $4.320,67$ & $€$ & $9.365,33$ \\
\hline 31 December 2017 & $€$ & $20.000,00$ & $9365,33 \times 31,57 \%$ & $2.956,63$ & $€$ & $6.408,70$ \\
\hline 31 December 2018 & $€$ & $20.000,00$ & $6408,70 \times 31,57 \%$ & $2.023,23$ & $€$ & $4.385,47$ \\
\hline 31 December 2019 & $€$ & $20.000,00$ & $4385,47 \times 31,57 \%$ & $1.384,49$ & $€$ & $3.000,98$ \\
\hline
\end{tabular}

Total depreciation for five years is $€ 17.000,00$ with scrap value of $€ 3.000,00$. 


\subsection{Sum of years' digits}

Like the reducing balance method, this method is also an accelerated method of depreciation. That means that the profit and loss account is charged in earlier years more than in the later years. Understanding of this method like to be find useful since it is an accepted method for apportioning interest charges over the life of a leased asset (Stittle, J. \& Robert T.W., 2008, p. 50). Under the SYD method, annual depreciation expense is determined by applying a constantly declining fraction to the depreciable cost (service value) of an asset.

The fraction to be applied in each year is determined as follows:

1. The years of service life of the asset are numbered in reverse order ( 1 for the last year, 2 for the next-to-last year, and so forth, until all years in the service life are assigned a number);

2. The sum of the numbers thus assigned is determined; and

3. The applicable fraction for each year has as its numerator the number assigned to the year in question and as its denominator, the numbers assigned to all years (Ann, T.B., 2011).

Based on the same example, the depreciable amount of $€ 17.000,00$ can be allocated to each year by using the denominator in equation $5+4+3+2+1=15$

The entries in profit and loss account and balance sheet would be as follows:

Table 4: Sum of years' digits method calculation

\begin{tabular}{cccccc}
\hline Date & Original value & Calculation & Depreciation & Net book value \\
\hline 31 December 2015 & $€$ & $20.000,00$ & $17000 \times 5 / 15$ & $5.666,67$ & $€ 4.333,33$ \\
\hline 31 December 2016 & $€$ & $20.000,00$ & $17000 \times 4 / 15$ & $4.533,33$ & $€ 9.800,00$ \\
\hline 31 December 2017 & $€ 20.000,00$ & $17000 \times 3 / 15$ & $3.400,00$ & $€ 6.400,00$ \\
\hline 31 December 2018 & $€$ & $20.000,00$ & $17000 \times 2 / 15$ & $2.266,67$ & $€ 4.133,33$ \\
\hline 31 December 2019 & $€$ & $20.000,00$ & $17000 \times 1 / 15$ & $1.133,33$ & $€ 3.000,00$ \\
\hline
\end{tabular}

Source: Author

It is interesting to compare the outcomes under the three different deprecation methods. What is noticeable is that deprecation charges are different in each year, but the total deprecation charge is identical. 
Table 5: Comparison of three methods of depreciation

\begin{tabular}{ccrrrrrr}
\hline $\begin{array}{c}\text { Deprecation charge in P\&L } \\
\text { account by year ended }\end{array}$ & Straight line & & Reducing balance & \multicolumn{2}{c}{ Sum of years' digits } \\
\hline 31 December 2015 & $€$ & $3.400,00$ & $€$ & $6.314,00$ & $€$ & $5.666,67$ \\
\hline 31 December 2016 & $€$ & $3.400,00$ & $€$ & $4.320,67$ & $€$ & $4.533,33$ \\
\hline 31 December 2017 & $€$ & $3.400,00$ & $€$ & $2.956,63$ & $€$ & $3.400,00$ \\
\hline 31 December 2018 & $€$ & $3.400,00$ & $€$ & $2.023,23$ & $€$ & $2.266,67$ \\
\hline 31 December 2019 & $€$ & $3.400,00$ & $€$ & $1.384,49$ & $€$ & $1.133,33$ \\
\hline TOTAL & $€$ & $17.000,00$ & $€$ & $16.999,02$ & $€$ & $17.000,00$ \\
\hline
\end{tabular}

Source: Author

The straight-line method is the most straightforward to apply, but it has the disadvantage that it does not seem to reflect the loss in value of a fixed asset over time. The two accelerated methods are reasonably similar and have the advantage of being closer reflection of economic reality. When analyzing financial statements, it is very important to have regard the company's depreciation policy (Stittle, J. \& Robert T.W., 2011, p. 51).

Depreciation can be also calculated based on use. In this case, annual depreciation would be calculated by multiplying numbers of kilometers realized in every year with depreciation rate per kilometer.

Original cost of truck

$€ 20.000,00$

Salvage value

Depreciable cost

$€ 17.000,00$

Estimated service life (kilometer)

200.000

Depreciation rate per kilometer (17000/200000)

$€ 0,085$

\section{Models for accounting tangible assets}

The calculation and reporting of depreciation is based upon two accounting principles:

- Cost principle - this principle requires that the depreciation expense reported on the income statement, and the asset amount that is reported on the balance sheet, should be based on the historical (original) cost of the asset.

- Matching principle - this principle requires that the asset's cost be allocated to depreciation expense over the life of the asset. 
There are three models available for accounting the production assets, including buildings and lands: ${ }^{3}$

1. Cost model under IAS 16;

2. Revaluation model under IAS 16, and

3. Fair value model under IAS 40.

The most common model is the cost model. Under this model, company holds assets at their cost less accumulated depreciation (less accumulated impairment losses if there are some). Sometimes, this model does not fit the situation well - for example, when company invested into a building with the purpose of selling it later. In addition, many companies do not apply the cost model properly, as they often forget to revise useful lives of their assets and as a result, they still use fully depreciated assets in the business. Revaluation model and fair value model have one common feature, its fair value, but they are very different.

Table 6: Fair value model vs. revaluation model

\begin{tabular}{|c|c|c|c|}
\hline & Fair value model & vs. & Revaluation model \\
\hline Which standard? & IAS 40 - Investment property & & IAS 16 - Property, plant and equipment \\
\hline \multirow{3}{*}{ What assets? } & For capital appreciation & & For production of goods/rendering services \\
\cline { 2 - 4 } & To earn rentals & & For rentals to others \\
\cline { 2 - 4 } & Buildings and lands only & & For administrative purposes \\
\hline \multirow{2}{*}{ How to apply? } & Keep at fair value & & Revalue regularly to fair value \\
\hline & Fair value changel in P/L & & Revaluation changes in equity \\
\hline Depreciation? & $* * * N O * *$ & & $* *$ YES*** \\
\hline
\end{tabular}

Source: Author, based on Silvia, M., https://www.ifrsbox.com/cost-revaluation-models-ppe-ifrs/

Under revaluation model, company should revalue its assets regularly to their fair value and depreciate revalued amount over remaining useful life. The important thing is that company can use revaluation model also for machinery (unlike fair value model) and charge depreciation (not under fair value model). Fair value model is prescribed as an option under IAS 40 - Investment Property. Under this model, company should value its assets at their fair value after initial recognition, with the fair value changes recognized in profit or loss. There is no depreciation. 


\subsection{Determining useful life}

IAS 16.57 defines the useful life of an asset in terms of the asset's expected utility to the entity. The asset management policy of the entity may involve the disposal of assets after a specified time or after consumption of a specified proportion of the future economic benefits embodied in the asset. Therefore, the useful life of an asset may be shorter than its economic life. The estimation of the useful life of the asset is a matter of judgement based on the experience of the entity with similar assets.

The standard IAS 16, paragraph 55 states that depreciation of an asset begins when it is available for use, or when it is in the desired location and condition. Depreciation of an asset ceases at the earlier of the date that the asset is classified as held for sale in accordance with IFRS 5 and the date that the asset is recognized. Therefore, depreciation does not cease when the asset becomes idle or is retired from active use unless the asset is fully depreciated.

However, under usage methods of depreciation the depreciation charge can be zero while there is no production. Terms "available for use" is not the same as "put into use", so here is one example. ${ }^{4}$

$\mathrm{ABC}$ Company acquired a machine for its new production line. The machine was delivered in February 20X1. Before putting it into use, an installation and testing performed by certified technician is required. All the work including tests were completed in April 20X1 and ABC launched the new production line in July 20X1.

In this example, available-for-use date is in April 20X1, put-into-use date is in July $20 \mathrm{X} 1$ when the new production line was launched, and $\mathrm{ABC}$ starts depreciating the machine in April $20 \mathrm{X} 1$.

Company starts depreciating an asset when it is available for use, but as there are no revenues produced yet (e.g. new production line has not been launched yet), the matching principle is in trouble. In other words, company has expenses (depreciation), but not the revenues. So next task is to select appropriate depreciation method.

IAS 16 does permit using several depreciation methods, such as number of units, diminishing balance, or simply any method that reflects the pattern in which the asset is consumed. Company can have zero depreciation charges in a non-production period. By this way, the tax rules of country need to be carefully considered, as many tax laws present only limited options for depreciation methods. It might not be permitted to apply zero depreciation charge in a non-production period. Depreciation is important in calculating taxes due. Federal tax law provides guidelines for determining estimated lives to be used for income tax purposes. An example, tax law

4 https://www.ifrsbox.com/when-start-depreciation/ 
in Bosnia and Herzegovina allows straight-line depreciation method. As a result, tax depreciation method might not correspond with the depreciation method selected under IAS 16 and tax depreciation will be different from accounting depreciation. Then story about deferred tax arises and it's quite complicated.

Due to King, A. M. (2011, p. 38) depreciation methods, amortization lives, fixed-asset lives and scrap values can and probably should differ between financial reporting and taxes. For financial reporting, how a taxpayer chooses lives, salvage values and depreciation methods for taxes in no way needs to govern what the company does for its own financial statements. Auditors, reviewing internal controls, will assure themselves that the client is following its own written accounting policies. Tax lives and depreciation methods have been developed to meet social and economic needs of the economy as a whole. They were not developed based on actual or expected economic utility.

King, A. M. (2011, p. 45) explains how valuation specialists determine economic lives. In valuing an existing factory full of equipment, the appraiser attempts to determine for each significant asset how much of the real useful life has been used up or expired and how much remains. The thought process looks at the economics of the operation, taking into consideration current maintenance policies and how well they are practiced. If you maintain car, changing the oil every 5000 miles, the car will last a lot longer than if you simply fill it up with gas and drive it until it falls apart. Preventive maintenance is the ,gold standard“: machinery and equipment appraisers are trained to evaluate what a company is doing, irrespective of what a written policy says is supposed to happen. Instead of an accountant setting the economic lives, the owner or user of the asset should determine the life.

\subsection{Determining depreciation expense}

Next problem with depreciation in manufacturing companies is connected with existing fully depreciated machinery. The problem is that as these machines are used beyond their useful life, they are fully depreciated and their carrying amount is zero. In this case, what depreciation expense can be recognized in the profit or loss? None, because the carrying amount cannot decrease below zero. Company has fully depreciated these assets in the previous reporting periods. As a result, the matching principle does not work again. The expenses simply do not match the benefits gained from these machines.

King, A. M. (2011, p. 40-41) notes that there is a very easy way to tell if you have been assigning appropriate lives to property in your company. Take the existing file and sort it by net book value. The chances are very high that there will be a substan- 
tial number of assets that have been fully depreciated, that show zero net book value and the assets are still present and still in use. By definition, a fully depreciated asset still in use had too short a life initially assigned. The rules in GAAP for setting lives and computing depreciation for financial reporting are not prescriptive. You are supposed to assign a life that corresponds to your best estimate of the expected useful (economic) life. The level of knowledge about manufacturing processes for most financial workers ranges from abysmal to none. Accountants should not be setting expected lives at all-other than for tax purposes.

IAS 16. 51 requires to review the residual value and the useful life of an asset at least at each financial year-end and, if expectations differ from previous estimates, the change(s) shall be accounted for as a change in an accounting estimate in accordance with IAS 8 - Accounting Policies, Changes in Accounting Estimates and Errors.

There are two possible corrective actions for situation when company still using fully depreciated assets in the production process. ${ }^{5}$

Solution 1: Review useful lives at each financial year-end.

Useful life is an accounting estimate and if company find out that it is different from what it has initially set, then this change needs to be booked in line with the standard IAS 8 - Accounting Policies, Changes in Accounting Estimates and Errors. After new remaining useful life is estimated, based on the carrying amount at the revision date and new, remaining useful life new revised depreciation charges will be calculated. No restatement of previous periods' financial statements is permitted. IAS 8 requires recognizing change in accounting estimates prospectively (now and in the future).

If the carrying amount (net book value) of company's assets is zero and if the useful lives in the past regularly were revised and during the current reporting period company find out that would like to use the assets even longer, then there's not much to do, then to leave these assets as they are and make sure to avoid this situation in the future.

On the other side, if company really forgot to revise the useful lives in the previous reporting period, this failure to apply $I A S 16$ results in the accounting error. If this error is material, then you should correct it retrospectively in line with $I A S$. It means restating the previous periods using the revised estimated useful lives.

Solution 2: Revalue your assets to their fair value.

IAS 16 permits two models for subsequent measurement of your property, plant and equipment: cost model and revaluation model. Revaluing machines with nil book value would effectively mean that you are changing your accounting policy and here

5 https://www.ifrsbox.com/machines-fully-depreciated-still-in-use/ 
the standard $I A S 8$ gets the word again. In line with $I A S 8$, company shall change the accounting policy only if the change results in the financial statements providing reliable and more relevant information about the effects of transactions, other events or conditions on the entity's financial position, financial performance or cash flows. Using revaluation model means that you need to apply the standard IFRS 13 - Fair Value Measurement in order to determine the fair value of your machines. It is very difficult to set the market value of used production machines, especially if they are so specific for relevant company. If you are ready to revalue machinery annually and you are ready to set the fair value for entire class of assets, then applying IAS 8 is easy for you and you do not need restatement of previous periods.

From the long-term point of view, revaluation model is not suitable for machines used in the production process, especially when they have a specialized nature and their main recovery lies in the production of other assets and not in the capital gains resulting from the movements of their market prices.

We should consider that depreciation expense, even people call it noncash charge, represents actual expense associated with the original purchase. The cost of an asset has to be reflected in the selling price of inventories made from that asset. It is very important that fixed assets are presented in balance sheet at proper value. In order to show the true financial position of the business in the balance sheet, it is necessary for assets to be shown at their true value, after deducting reasonable depreciation. If depreciation were not provided, the assets would be overstated in the balance sheet (Ramagopal, C, 2009, p. 157).

\section{CONSLUSIONS}

By extending the useful lifespan of tangible assets, company will have no effect on cash flow, because depreciation expense is not a source of cash. That means that there is no positive impact on producing additional funds. Positive impact will be on reporting increased income. EBITDA - Earnings before interest, taxes, depreciation and amortization is also not affected by the choice of useful lifespan for calculating depreciation. Determining correct depreciation expenditure will give a better picture of true profitability. If company use aggressive depreciation charges, the stated net profit will be underestimated or overestimated. In Bosnia and Herzegovina, the absorption system for cost calculation is mainly in use, so aggressive depreciation will result with higher cost per product that may lead to incorrect product pricing, as well as incorrect financial analysis of the relative profitability. This is a point mainly emphasized in cost accounting courses in colleges and universities. 
Managers are interested in depreciation expense, because there is indirect influence of depreciation on cash flow. If a company uses inadequate useful lifespan and has low depreciation expenses, it would negatively affect cash flow, due to disbursements for dividends that would be made from overstated earnings. Not only managers are interested in depreciation expenses. It is useful to know depreciation amount in order to calculate EBITDA, because it can be useful for some predictions and business analysis, if there is doubt in reliability of net income. Public service commissions, management, customers, taxing authorities and investors are mainly interested in depreciation expenses. Depreciation accounting helps to determine appropriate balance-sheet values for assets, to determine periodic earnings, and to maintain invested capital by allocating the costs of tangible plant assets over the service lifespan of the assets.

Depreciation expense on the income statement reduces the asset value in balance sheets. That is the main connection between these two statements. Accelerated depreciation will mean larger depreciation expenses in the early years of the asset's lifespan and then smaller depreciation expenses in the later years. Carrying amount at the end of the useful lifespan will be the same, but during operation, if using accelerated depreciation, the value of property will be underestimated. These larger expenses in the earlier years will mean that the company will report less profit in the earlier years of an asset's lifespan. The accelerated depreciation brings underestimated earnings and underestimated property net value. Therefore, the hypothesis that incorrect depreciable amount in IFRS financial statements is not result of different depreciation methods application, but inconsistent application changes in accounting estimates is correct.

In connection with the concern over maintenance of invested capital, it has been suggested that depreciation charges should be based on the cost of replacing property as opposed to the original cost of the plant. This option can be useful for making a budget in terms of replacement cost for managers who have had to secure funds for plant replacement, improvement, and expansion in the future. Many non-accountants believe that depreciation creates a fund that will provide for the purchase of new investment in the future. This is not what the current data indicate, because new investments can be carried out trough current profits or trough borrowing. The purpose of depreciation is to maintain the original capital base of the company by acting as a constraint on the amount of profits available for distribution as dividends. It is important to emphasize that the depreciation concept is not designed to provide a means or method to replace ageing assets or that it was intended to be a saving-scheme by which the company can fund purchases of new assets. 


\section{REFERENCES}

1. Ann, T. B. 2011. Financial Management for Water Utilities: Principles of Finance, Accounting and Management Controls, American Water Works Assoc.

2. Appannaiah, H. R., et al. 2010. Financial Accounting 2, Himalaya Publishing House.

3. Carmichael, D. R. and Whittington O. R., 2012. Accountants' Handbook, Financial Accounting and General Topics, John Wiley \& Sons, Incorporated, [online]. ProQuest Ebook Central: https://ebookcentral.proquest.com/lib/linkgroup-ebooks/detail.action?docID=821930. [Accessed on May 20, 2019].

4. David, L. and Wong, N., 2010. Issues in financial accounting and reporting: Issues in Financial Accounting and Reporting, Emerald Publishing Limited, [online]. ProQuest Ebook Central: https://ebookcentral.proquest.com/lib/linkgroup-ebooks/detail.action?docID=647734. [Accessed on May 21, 2019].

5. Gangwar, S. and Gangwar, D.K. 2008. Fundamental Principles of Accounting, Global Media.

6. International accounting standard 16 - Property, Plant and Equipment, Available on: https://www.iasplus.com/en/standards/ias/ias16. [Accessed on May 25, 2019].

7. International accounting standard 8 - Accounting Policies, Changes in Accounting Estimates and Errors. Available on: https://www.iasplus.com/en/standards/ ias/ias8. [Accessed on May 15, 2019].

8. Jahić, M., Jahić, H., Isaković-Kaplan, Š. 2012. Finansijsko računovodstvo, Udruženje revizora $\mathrm{FBiH}$.

9. Jahić, M., Bašić, M., Isaković-Kaplan, Š. and Arnautović, A. 2005. Financial accounting: handbook, Ekonomski fakultet, Sarajevo.

10. Kapić, J. 2011. Računovodstvo, Ekonomski fakultet, Sarajevo.

11. King, A. M. 2011. Internal Control of Fixed Assets: A Controller and Auditor's Guide, John Wiley \& Sons, Incorporated.

12. Mahutova, S., 2019. How to account for free assets received under IFRS, [online]. Available at: https://www.ifrsbox.com/free-assets-ifrs-gifts/. [Accessed on May 15, 2019].

13. Mahutova, S., 2019. Out machines are fully depreciated, but we still use them! What shall we do, [online]. Available at: https://www.ifrsbox.com/machines-fully-depreciated-still-in-use/.[Accessed on May 15, 2019].

14. Mahutova, S., 2019. 3 biggest myths in accounting for PPE, [online]. Available at: https://www.ifrsbox.com/cost-revaluation-models-ppe-ifrs/__[Accessed on May 15, 2019]. 
15. Nothhelfer, R., 2017. Financial Accounting : Introduction to German GAAP with Exercises, Walter de Gruyter GmbH, [online] ProQuest Ebook Central: https://ebookcentral.proquest.com/lib/linkgroup-ebooks/detail.action?do$\mathrm{cID}=5144620$.

16. Ramagopal, C. 2009. Accounting for Managers, New Age International Ltd.

17. Rauf, S. B. 2010. Finance and Accounting for Energy Engineers, The Fairmont Press, Inc.

18. Singh, Y.P. 2007. Accounting and Financial Management for I.T. Professionals, New Age International Ltd.

19. Smith, B. 2010. Introductory Financial Accounting, McGraw-Hill Education.

20. Stittle, J. and Robert T. W. 2008. Financial Accounting, SAGE Publications.

\section{PROBLEMI OBRAČUNA AMORTIZACIJE MATERIJALNIH STALNIH SREDSTAVA}

\section{SAŽETAK}

Zgrade, mašine, oprema, namještaj, računari, parking prostori, automobili i kamioni primjeri su materijalnih stalnih sredstava koja ne traju neograničeno, ali traju više od godinu dana. Tokom svakog obračunskog perioda dio nabavne vrijednosti ove imovine se prenosi na troškove. Svaka kompanija, svojim osnivanjem, nabavlja materijalna stalna sredstva kao osnovu za svoje poslovanje. Ako ste izvršni finansijski direktor proizvodnog preduzeća, neće biti neobično ako u jednom momentu spoznate da su neka od vaših proizvodnih sredstava još uvijek u pogonu, ali su potpuno amortizovane. U tom slučaju postajete svjesni da ne poštujete osnovni računovodstveni princip za izvještavanje o dugoročnoj imovini (princip sučeljavanja prihoda i troškova). Način na koji direktor rješava ovaj problem može imati veliki utjecaj na cijenu koštanja i finansijski rezultat na kraju godine. Problem je što korisni vijek imovine nije pravilno procijenjen ili revidiran. Kao rezultat, knjigovodstvena vrijednost i finansijski rezultat u finansijskim izvještajima nisu tačni. Rješavanje ovog problema je veoma važno i neophodno za kreiranje pouzdanih konsolidovanih izvještaja $i$ za prezentiranje finansijskih izvještaja u skladu sa Međunarodnim standardima finansijskog izvještavanja, posebno ako finansijske izvještaje revidiraju velike revizorske kuće. Cilj ovog rada je da pomogne u razumijevanju teorijskih i praktičnih pitanja o materijalnim stalnim sredstvima, posebno amortizaciji, kroz analizu dostupne literature, naučnih radova pisanih u svijetu i praktičnih istraživanja autora.

Ključne riječi: materijalna stalna sredstva, amortizacija, vijek upotrebe, revalorizacija. 